
\title{
28 Research Square \\ Ion Exchange Capacity of Synthetic Zeolite L: A Promising Way for Cerium Recovery
}

\section{Giorgia Confalonieri}

European Synchrotron Radiation Facility

Giovanna Vezzalini

University of Modena and Reggio Emilia

Laura Maletti

University of Modena and Reggio Emilia

Francesco Di Renzo

Institut Charles Gerhardt de Montpellier

Vittorio Gozzoli

University of Modena and Reggio Emilia

Rossella Arletti ( $\nabla$ rossella.arletti@unimore.it)

University of Modena and Reggio Emilia Department of Chemical and Geological Sciences https://orcid.org/0000-0001-9878-8657

\section{Research Article}

Keywords: Ce recovery, Zeolite L, Cation exchange, Waste recovery, Exchange kinetic, Zeolite absorption capacity

Posted Date: January 20th, 2022

DOI: https://doi.org/10.21203/rs.3.rs-1174126/v1

License: (c) (1) This work is licensed under a Creative Commons Attribution 4.0 International License.

Read Full License 


\section{Abstract}

Due to the increasing demand for Rare Earth Elements (REE) and the current political scenario, it is essential to recover these elements from industrial or mining waste. Zeolites are microporous materials little investigated for REEs recycle. Here, we propose the use of $\mathrm{NH}_{4}{ }^{+}$-exchanged synthetic zeolite $\mathrm{L}$ for cerium recovery from a solution mimicking the $\mathrm{Ce}^{3+}$ concentration of the liquors deriving from the recovery of spent catalysts $(0.002 \mathrm{M})$. $\mathrm{A} \mathrm{NH}_{4}{ }^{+}$-exchanged sample was used since the presence of only ammonium as exchangeable cation in the zeolite porosities greatly simplifies the Ce recovery once the exchange is accomplished. The aim of this work is twofold, in fact we want to investigate the exploitability of zeolite $L$ as cation exchanger in the Ce recovery and determine the best working conditions. The investigated process consists of a coupled cation exchange: 1) $\mathrm{Ce}^{3+}$ (solution) $+3 \mathrm{NH}_{4}{ }^{+}+$ (zeolite) $\leftrightarrow \mathrm{Ce}^{3+}$ (zeolite) $+3 \mathrm{NH}_{4}{ }^{+}+$(solution). In the first exchange the $\mathrm{NH}_{4}{ }^{+}$cations - present in the zeolite porosities- are exchanged with the $\mathrm{Ce}^{3+}$ of the solution and in the second experiment the $\mathrm{Ce}^{3+}$ trapped into the zeolite is recovered through a further exchange with the $\mathrm{NH}_{4}{ }^{+}$of a rich solution. The best working conditions for $\mathrm{Ce}^{3+}$ exchange of $\mathrm{NH}_{4}-\mathrm{L}$ are: batch system, liquid/solid ratio equal to $90 \mathrm{~mL} / \mathrm{g}$ and 180 $\mathrm{mL} / \mathrm{g}, 24 \mathrm{~h}$ of contact at $25^{\circ} \mathrm{C}$. The resulting cerium adsorption capacity $\left(\mathrm{q}_{\mathrm{t}}\right)$ is equal to $\sim 25 \mathrm{mg} / \mathrm{g}$ and $\sim 39 \mathrm{mg} / \mathrm{g}$ and the removal efficiency $100 \%$ and $77 \%$ for the two tested liquid/solid ratios, respectively. The kinetics was proved to be fast and consistent with industrial timing, no energy cost for temperature setting is required and the acid $\mathrm{pH}(\sim 4)$ of the solutions does not affect the zeolite structure stability and its exchange performance. At these conditions, cerium of the solution was first incorporated into the zeolite porosities and then completely recovered. It has been demonstrated that the zeolite framework is not affected by the exchange so that the same absorbent can be employed many times.

\section{Introduction}

Nowadays, the demand for Rare Earth Elements (REE) is increasing due to their extensive use in many technological fields. However, the current political scenario -where REE are considered as strategic resources (Mancheri et al. 2019, Charalampides et al. 2015)-, the monopoly of only a few countries in the export of these materials, the so-called balance problem between demand and natural abundance (Binnemans et al. 2018), and the need to limit the environmental costs of their mining (Haque et al. 2014, Suli et al. 2017), stress the necessity of a recycling policy of these elements and of their recovery from industrial and mining waste. In terms of volumes, one of the most exploited REE is cerium (Charalampides et al. 2015, Binnemans et al. 2018), which is employed in a huge number of devices such as NiMH batteries (Porvali et al. 2020), fluid catalytic cracking (FCC) catalysts (Innocenzi et al. 2015), redox support for three-ways automotive catalysts and other metal catalysts (Gorte 2010), glass polishing and glass films (Borra et al. 2018), and fluorescent lamps (Tunsu et al. 2016), Yurramendi et al. 2019). These materials contain a variable amount of REEs; for example, cerium dioxide reaches 40-99 wt \% in glass polishing waste (Meshram \&Abhilash 2020) -where cerium is the most abundant REE, being at least $65 \mathrm{wt} \%$ of the whole REEs content (Binnemans et al. 2013)- and $5.3 \mathrm{wt} \%$ in automotive catalysts 
(Zhao et al. 2020), while in FCC cerium is 0.2-0.3 wt \% (Meshram \&Abhilash 2020), only 10 wt \% of the total REEs amount (Binnemans et al. 2013). The liquors obtained by leaching these exhausted components can present, thus, different cerium concentrations, from $\sim 0.02 \mathrm{M}$ for the leached solutions coming from the residual waste of exhausted automobile catalysts (llyas et al. 2021) to $0.002 \mathrm{M}$ for FCC (Innocenzi et al. 2015). A strategy for the extraction of Ce from these acid solutions is mandatory for the efficient recycling of this metal. Different methods were already tested for REEs recovery such as precipitation (double salt precipitation, oxalate precipitation, carbonate precipitation, hydroxide precipitation), solvent extraction (Meshram \&Abhilash 2020), adsorption (de Farias et al. 2021) or ion exchange (Royen \&Fortkamp 2016). This last is usually applied using MOF or resin, however, efficient recycling can be achieved using other porous materials such as zeolites.

Zeolites are microporous natural and synthetic materials with various frameworks and pore systems and characterized by: i) open structures, which makes them good molecular sieves; ii) ion exchange capacity; iii) catalytic properties; iv) adsorption capacity; v) reversible dehydration. Due to these properties, they can be exploited for energy storage purposes (Eroshenko et al. 2001, Soulard \&Patarin 2011, Krajnc et al. 2017, Confalonieri et al. 2018, Confalonieri et al. 2020) (, as agriculture amendments (Ramesh et al. 2011, Eroglu et al. 2017, Nakhli et al. 2017, Mendez-Arguello \&Lira-Saldivar 2019), in medicine as drug delivery systems (Stylianou 2012, Bacakova et al. 2018), as scaffolds for organic molecules (Calzaferri et al. 2003, Gigli et al. 2018, Fabbiani et al. 2021) (in many technological applications, for $\mathrm{CO}_{2}$ adsorption (Hong et al. 2014, Coudert \& Kohen 2017, de Aquino et al. 2020), in catalysis (Corma 2003, Čejka et al. 2010), etc.

Despite the promising ion exchange properties of zeolites, just a few preliminary works investigated their use for REEs recycling (Faghihian et al. 2005, Duplouy 2016, Barros et al. 2019, Mosai et al. 2019) thus, their potential application to recover these elements from acid-leached liquors of industrial waste should be deeper explored.

In the present paper, we tested the efficiency of a $\mathrm{NH}_{4}{ }^{+}$- exchanged zeolite $\mathrm{L}\left(\mathrm{NH}_{4}-\mathrm{L}\right)$ in Ce recovery from acid solutions. Zeolite K-L was reported in a work of Duplouy as a promising candidate, among various tested zeolites (FER and FAU), for REEs recovery (Duplouy 2016). A recent study by our group investigated the Ce exchange capacity of three different cationic forms of zeolite $L$ through chemical analyses and $X$ Ray Powder Diffraction (XRPD) structural investigations (i.e. original as synthesized $\mathrm{K}^{+}$, and $\mathrm{Na}^{+}$and $\mathrm{NH}_{4}{ }^{+}$exchanged forms) (Confalonieri et al. 2021) and proved the efficacy of this zeolite in exchanging $\mathrm{Ce}^{3+}$ from highly concentrated solutions. The structural study gave new insight on the sites involved in the exchange, and even if it demonstrated that cation exchange capacity for Ce is not influenced by the nature of the extraframework cations, showed that for the $\mathrm{NH}_{4}{ }^{+}$exchanged sample, the Ce recovery from zeolite porosities is complete.

For the above-mentioned reasons, in the present work, zeolite L, precisely $\mathrm{NH}_{4}{ }^{+}$- exchanged form, was chosen to test the effectiveness in exchanging cerium from a very diluted solution $\left(\left[\mathrm{Ce}^{3+}\right]=0.002 \mathrm{M}\right)$, 
which mimics the concentration reported for residual liquor of FCC waste (Innocenzi et al. 2015). We experimented different liquid/solid (l/s) ratios, and to follow the requirements of a green process, the temperature was maintained at $25^{\circ} \mathrm{C}$. In fact, several tests performed at higher (but mild) temperature did not indicate improvements in the cations exchange process. This work aims to target the optimum experimental setting to remove $\mathrm{Ce}^{3+}$ from the solution, concentrating it inside the zeolite pores. In a second step, the extraction of cerium from the Ce-exchanged LTL is obtained through a reverse exchange in a $\mathrm{NH}_{4}{ }^{+}$solution. This final exchange is proposed to recover the cerium ions for further utilization by fully exploiting the reversibility of cation exchange in zeolites (Figure 1).

This work is part of a wider project aimed at exploiting zeolite cation exchange properties to recover REE from waste, to move toward a green circular economy model. In fact, although some conventional adsorbents display high adsorption capacity, they have several limitations, including expensive production and difficult regeneration. Using zeolites for REE recovery will offer the possibility to exploit a material that can be recycled many times (probably for infinite cycles) and that does not need to be regenerated, since once the $R E E$ is recovered, the powder can be immediately reused.

We started by testing synthetic zeolites, since the use of pure materials allows a clearer understanding of the process occurring during the exchange and an easier following of the exchange kinetics. The further step of the project, to pursue a greener process, will the exploitation of natural zeolites, this in fact will allow the use of cheap materials, without the need of a dedicated synthesis, allowing further energy saving. In addition, the use of an $\mathrm{NH}_{4}{ }^{+}$solution for the first and final exchange will allow the use of the same solution for several exchange cycles, so to avoid waste of chemicals during the treatment stages.

\section{Experimental Section \\ 2.1. Zeolite L}

The synthetic zeolite $L$ has formula $\left(\mathrm{K}_{6} \mathrm{Na}_{3}\left(\mathrm{H}_{2} \mathrm{O}\right)_{21} \mathrm{Al}_{9} \mathrm{Si}_{27} \mathrm{O}_{72}, a=18.4 \AA \mathrm{A}=7.52 \AA, \gamma=120^{\circ}\right)$ and $\mathrm{LTL}$ framework type (Baerlocher \&McCusker). This framework is composed by small cages (cancrinite cages) and two mono-dimensional channels both running along the $c$ axis of the unit cell: a channel built by connection of rings of 12 tetrahedra (12MR) and a smaller elliptical one delimited by rings of 8 tetrahedra (8MR). In the as-synthesized $\mathrm{K}$ form, cations occupy different crystallographic positions: two of them participate to the cation exchange - being hosted in the channels, while those hosted in the cages cannot be exchanged. The $\mathrm{NH}_{4}{ }^{+}$exchanged form of synthetic $\mathrm{K}-\mathrm{L}$ zeolite $\left(\mathrm{NH}_{4}-\mathrm{L}\right.$ from now on), with chemical formula $\mathrm{K}_{2.25}\left(\mathrm{NH}_{4}\right)_{6.86} \mathrm{Si}_{26.91} \mathrm{Al}_{9.08} \mathrm{O}_{72} \cdot 17.07\left(\mathrm{H}_{2} \mathrm{O}\right)$, was fully characterized in Confalonieri et al. (2021). In the exchanged form, $\mathrm{NH}_{4}{ }^{+}$ions substitute $\sim 75 \%$ of the original $\mathrm{K}$ and are hosted just in the two channels (Figure 2). $\mathrm{NH}_{4}{ }^{+}$-exchanged form was chosen for this study since once the Ce exchange will be obtained, the zeolite will be further $\mathrm{NH}_{4}{ }^{+}$exchanged to recover cerium from inside the zeolite porosities. In this way, the presence of $\mathrm{NH}_{4}{ }^{+}$as unique exchangeable cation in the starting material will allow to obtain a final 
recovery solution containing only ammonium (easily removable and recyclable by evaporation) and cerium.

\subsection{Cerium Exchange}

A $0.002 \mathrm{M} \mathrm{Ce}^{3+}$ solution was prepared dissolving $\mathrm{Ce}(\mathrm{NO} \otimes) \otimes \cdot 6 \mathrm{H} 囚 \mathrm{O}$ (Cerium(III) nitrate hexahydrate, REacton ${ }^{\circledR}, 99.5 \%$ (REO) - Alfa Aesar) into double-distilled water. $\mathrm{NH}_{4}-\mathrm{L}$ zeolite was put in contact for $72 \mathrm{~h}$ with the solution at $25^{\circ} \mathrm{C}$ under stirring. The $\mathrm{pH}$ was initially set to 4.3 using $\mathrm{HNO}_{3}$ to avoid cerium compound precipitation and to mimic the acid conditions of a real industrial waste liquor. The stability of the zeolite framework in this $\mathrm{pH}$ condition was tested in order to exclude the possibility of a dealumination process or structural modifications. The $\mathrm{pH}$ of the solution was constantly monitored showing a maximum variation from 4.3 to 4.9 after $72 \mathrm{~h}$ of contact with the zeolite. No buffer solution was used to avoid competition in the zeolite ion exchange. Various experiments were performed using different liquid/solid ratios $(30,60,90,180,290,750 \mathrm{~mL} / \mathrm{g})$ and the same contact time of $72 \mathrm{~h}$. Several tests were performed at higher temperatures (up to $80^{\circ} \mathrm{C}$, data not reported), but, since they did not indicate improvements in the cations exchange process, we decided to work at room temperature. The exchanged samples were labelled $\mathrm{Ce}-X$, where $X$ is the liquid/solid ratio in $\mathrm{mL} / \mathrm{g}$. At the end of the process, all the exchanged zeolites were rinsed three times with double-distilled water using an ALC multispeed centrifuge PK 121, operated at $5000 \mathrm{rpm}$ for $10 \mathrm{~min}$. The samples were finally dried at $60^{\circ} \mathrm{C}$ for 24 h.

\subsection{Cerium recovery}

All the Ce-exchanged zeolites, obtained as described in the previous section, were contacted for $24 \mathrm{~h}$ under stirring, at room temperature, with a solution $\left[\mathrm{NH}_{4}{ }^{+}\right]=0.8 \mathrm{M}$ prepared dissolving $\mathrm{NH}_{4} \mathrm{NO}_{3}$ (ammonium nitrate, 99\%, Carlo Erba) in double-distilled water. The liquid/solid ratio was $60 \mathrm{~mL} / \mathrm{g}$, pH was not set. Zeolite samples so obtained are identified with the prefix Rev. At the end of the $\mathrm{NH}_{4}{ }^{+}$-exchange, the powders were washed, dried following the procedure reported above, and analysed to check the cerium recovery.

\subsection{Analytical methods}

- Inductively Coupled Plasma (ICP) Analysis: the kinetic of $\mathrm{Ce}^{3+}$ exchange was monitored daily analysing the exchange solutions with ICP-OES technique. A small fraction of supernatants was withdrawn from the solutions, filtered by cellulose nitrate membrane $(0.45 \mu \mathrm{m})$ and properly diluted. ICP analysis was performed using a Perkin Elmer Optima 4200 DV to measure the cerium content. Three analyses were performed for each sample and the initial solution with $\left[\mathrm{Ce}^{3+}\right]=0.002 \mathrm{M}$ was also analysed and used as reference.

- Thermogravimetric Analysis (TG): Seiko SSC/5200 thermal analyser was employed to perform thermogravimetric analysis. The temperature range was room temperature (r.t.) $-1050^{\circ} \mathrm{C}$ with a ramp of $10^{\circ} \mathrm{C} / \mathrm{min}$ under air flow. 
- Elemental Analysis: nitrogen content of zeolite samples was detected through Flash 2000 CHNS/MAS200R instrument. "FLASH" dynamic combustion (modified Dumas method) allows to treat the sample at $1800^{\circ} \mathrm{C}$. Released elementary gases are separated through a chromatographic column and detected by a highly sensitive thermal conductivity (TCD) detector.

- SEM-EDS analysis: chemical analyses of the exchanged zeolites were performed by a scanning electron microscope (SEM) Nova NanoSEM 450 equipped with X-EDS Bruker QUANTAX-200 detector. Samples were prepared compressing the zeolite powders into thin self-supporting discs, then coated with gold. The instrument operated at $15 \mathrm{kV}$, five analyses for each sample were performed scanning the beam to avoid dehydration and cation migration in the zeolite and the intensities were corrected using the phi-rho- $Z$ method.

- X-Ray Powder Diffraction (XRPD): diffraction patterns of the original $\mathrm{NH}_{4}-\mathrm{L}$ (Confalonieri et al. 2021), Ce90, Ce-180, Rev-Ce-90 and Rev-Ce-180 were collected at ID22, high resolution beamline, of European Synchrotron Radiation Facility, Grenoble using the new Extremely Brilliant Source (EBS). Wavelength was set at $0.35426696 \AA$, diffraction intensities were recorded by an Eiger2 X CdTe 2M-W detector preceded by a13 Si(111) analyser crystals. Powder patterns were collected in Debye-Scherrer geometry.

\section{Results And Discussion}

\subsection{Cerium exchange of $\mathrm{NH}_{4}-\mathrm{L}$}

The results of elemental (Table S1) and SEM-EDS (Table S2) analyses, performed on the exchanged zeolite samples are reported in the Supporting Information, while thermogravimetric analyses and chemical formulas are shown in Figure 3 and Table 1 respectively.

Table 1. Chemical formula of Ce-exchanged $\mathrm{NH}_{4}-\mathrm{L}$ zeolites calculated from EDS analysis with nitrogen and $\mathrm{H}_{2} \mathrm{O}$ content determined by elemental and TG analysis, respectively. Error of the analyses is calculated as reported in (Gottardi \&Galli 1985) using the following formula: Error $\%=\frac{A l-K-\mathrm{NH}_{4}-3 \mathrm{Ce}}{\mathrm{K}+\mathrm{NH}_{4}+3 \mathrm{CE}} \cdot 100$.

\begin{tabular}{lll}
\hline Sample & Chemical Formula & Error (\%) \\
\hline NH4-LTL & $\mathrm{K}_{225}\left(\mathrm{NH}_{4}\right)_{6.86} \mathrm{Si}_{26.91} \mathrm{Al}_{9.08} \mathrm{O}_{72}-17.07 \mathrm{H}_{2} \mathrm{O}$ & -0.3 \\
\hline $\mathrm{Ce}-30$ & $\mathrm{~K}_{215} \mathrm{NH}_{4} 6.30 \mathrm{Ce}_{0.18} \mathrm{Si}_{26.80} \mathrm{Al}_{9.24} \mathrm{O}_{72} 17.56 \mathrm{H}_{2} \mathrm{O}$ & 2.90 \\
$C e-60$ & $\mathrm{~K}_{219} \mathrm{NH}_{4} 5.95 \mathrm{Ce}_{0.37} \mathrm{Si}_{26.77} \mathrm{Al}_{9.21} \mathrm{O}_{72} 17.71 \mathrm{H}_{2} \mathrm{O}$ & -0.47 \\
$C e-90$ & $\mathrm{~K}_{216} \mathrm{NH}_{4} 5.47 \mathrm{Ce}_{0.55} \mathrm{Si}_{26.79} \mathrm{Al}_{9.15} \mathrm{O}_{72} 18.90 \mathrm{H}_{2} \mathrm{O}$ & -1.59 \\
$C e-180$ & $\mathrm{~K}_{211} \mathrm{NH}_{4} 4.97 \mathrm{Ce}_{0.87} \mathrm{Si}_{26.67} \mathrm{Al}_{9.19} \mathrm{O}_{72} 19.92 \mathrm{H}_{2} \mathrm{O}$ & -6.29 \\
$C e-290$ & $\mathrm{~K}_{1.97} \mathrm{NH}_{44.62} \mathrm{Ce}_{0.93} \mathrm{Si}_{26.70} \mathrm{Al}_{9.26} \mathrm{O}_{72} 20.00 \mathrm{H}_{2} \mathrm{O}$ & -1.59 \\
$C e-750$ & $\mathrm{~K}_{1.89} \mathrm{NH}_{4} 4.44 \mathrm{Ce}_{0.97} \mathrm{Si}_{26.69} \mathrm{Al}_{9.30} \mathrm{O}_{72} 20.09 \mathrm{H}_{2} \mathrm{O}$ & 0.82 \\
\hline
\end{tabular}


As evident in Table 1, the $\mathrm{H}_{2} \mathrm{O}$ content increases with the cerium amount. This is because i) $\mathrm{Ce}^{3+}$ has a larger solvation sphere in comparison to $\mathrm{NH}_{4}{ }^{+}$( 9.1 (Lutz et al. 2012) versus 5.8 (Chang \& Dang 2003) $\mathrm{H}_{2} \mathrm{O}$ molecules in the first hydration shell, respectively); ii) due to the reduced number of cations (trivalent Ce vs monovalent cations), in the samples with a higher amount of cerium more space is available in the main 12MR channel (Confalonieri et al. 2021). The weight loss imputable to $\mathrm{H}_{2} \mathrm{O}$ (the first peak of the DTG curves (Figure 3) corresponds to 11.7 wt \%, 11.7 wt \%. 12.4 wt \%. 12.8 wt \%, 12.9 wt \% and 12.9 for samples Ce-30, Ce-60, Ce-90, Ce-180, Ce-290 and Ce-750, respectively. The shift at higher temperature of the first peak of DTG as a function of the liquid/solid ratio is related to the higher cerium content of the samples. In fact, being the bonds between the $\mathrm{H}_{2} \mathrm{O}$ molecules and Ce stronger with respect to those with ammonium ions, the $\mathrm{H}_{2} \mathrm{O}$ molecules are released at higher temperature (Confalonieri et al. 2021). The weight losses above $300^{\circ} \mathrm{C}$ are related to the $\mathrm{NH}_{4}{ }^{+}$loss. TG results suggest a slightly higher $\mathrm{NH}_{4}{ }^{+}$content for samples with low liquid/solid ratio, corresponding to a lower Ce exchange, in agreement with elemental analyses (Table S1).

The kinetics of the $\mathrm{Ce}^{3+}$ exchange was monitored every $24 \mathrm{~h}$ for each exchange experiment carried out (Figure 4 and Table S3).

From ICP results (Figure 4 and Table S3) it is clear that the $\mathrm{Ce}^{3+}$ concentration into the solution decreases for all the liquid/solid ratios tested, so confirming that $\mathrm{NH}_{4}-L$ zeolite extracts $\mathrm{Ce}^{3+}$ from the solutions. The exchange occurs mainly in the first $24 \mathrm{~h}$ (Figure 4, bottom panel) and affects mainly the $\mathrm{NH}_{4}{ }^{+}$ions $($Table 1). A slight decrease in the $\mathrm{K}$ content with respect to starting $\mathrm{NH}_{4}-\mathrm{L}$ sample is observed (Table 1 ), showing that some residual $\mathrm{K}$ can be further exchanged by Ce (see discussion below). The data after $72 \mathrm{~h}$ of contact is stable enough to be considered as equilibrium values (Table S3) and the experiments with different residual $\mathrm{Ce}^{3+}$ amounts in solution allow to establish an experimental $\mathrm{Ce}^{3+}-\mathrm{NH}_{4}{ }^{+}$exchange isotherm, shown in Figure 5. The experimental points are expressed as $\mathrm{Az} v \mathrm{As}$, where $\mathrm{Az}=3 \mathrm{Ce}^{3+} / \mathrm{Al}$ (molar) in the zeolite and $\mathrm{As}=\mathrm{C}\left(\mathrm{Ce}^{3+}\right) /$ initial $\mathrm{C}\left(\mathrm{NH}_{4}{ }^{+}\right)$(equivalents) in solution. The isotherm can be fitted by a constant separation factor model $A z=\left(K A s A z_{\max }\right) /(1+K$ As $)$, in which $K=a_{B}{ }^{A}-1$, where $a_{B}{ }^{A}=(A z / A s) /(B z / B s)$ is the separation factor, in which $\mathrm{Bz}=\mathrm{NH}_{4}{ }^{+} / \mathrm{Al}$ (molar) in the zeolite and Bs $=\mathrm{C}\left(\mathrm{NH}_{4}^{+}\right) /$initial $\mathrm{C}\left(\mathrm{NH}_{4}^{+}\right)$(equivalents) in the solution (LeVan et al. 1997) (Breck 1984). The value of the separation factor of the exchange of cerium for ammonium is 67 , indicating a much higher affinity of $\mathrm{NH}_{4}-\mathrm{L}$ for cerium than for ammonium. Such a value is not uncommon in the exchange of multivalent monovalent cations in zeolites (Breck 1984). The isotherm reaches an asymptotic value of $A z_{m a x}$ at 0.31 . This corresponds to a clear limit of cerium content at $\sim 1 \mathrm{Ce}$ atom p.u.c.. This value is very close to the 1.17 Ce p.u.c. reported for the $\mathrm{NH}_{4}{ }^{+}$- exchanged zeolite $\mathrm{L}$ using a highly concentrated cerium solution, which represents the maximum Ce adsorption in zeolite $L$ and involves only sites positioned in the main channel (Confalonieri et al. 2021). 
In conclusion, cerium cannot saturate all the anion sites of zeolite $L$, however, the aim of this work is not to obtain the complete cation exchange of the zeolite, but rather to define the best conditions to recover Ce from a very diluted liquor. In particular, we would like: 1) to obtain an efficient uptake of cerium, reducing at the minimum the cerium left in the solution and, in the meantime 2) to achieve a high concentration of $\mathrm{Ce}$ in the zeolite to reduce the number of uptake-recovery cycles; 3 ) to prove that the same zeolite powder can be used many times to recover Ce from solutions. Among the tested systems, two demonstrated to be the most suitable for these purposes $\mathrm{Ce}-90$ and $\mathrm{Ce}-180$, that show an exchange of the cerium from the solution equal to the $100 \%$ and $77 \%$ (Figure 4 and Table S3) in the first $24 \mathrm{~h}$ and incorporating in zeolite porosities 0.55 and 0.87 cerium ions p.u.c., respectively (Table 1).

\subsection{Cerium recovery}

The cerium recovery from the Ce exchanged zeolites was fulfilled through a further exchange with a $\mathrm{NH}_{4}{ }^{+}$ $0.8 \mathrm{M}$ solution. The chemical composition of the zeolite samples recovered after the final $\mathrm{NH}_{4}{ }^{+}$-exchange is reported in Table S4, while the comparison between $\mathrm{Ce}_{2} \mathrm{O}_{3}$ and $\mathrm{N}$ wt\% present in the zeolite channels before and after the Ce recovery process (i.e. $\mathrm{NH}_{4}{ }^{+}$exchange) is shown in Tables 2 and $\mathrm{S} 5$, respectively.

Table 2

Cerium oxide (wt \%) in zeolite samples before and after $\mathrm{NH}_{4}{ }^{+}$exchanges (i.e. after Ce recovery), from EDS analysis.

\begin{tabular}{|llll|}
\hline Name & $\mathrm{Ce}_{2} \mathrm{O}_{3}(\mathrm{wt} \%)$ & Name & $\mathrm{Ce}_{2} \mathrm{O}_{3}$ (wt \%) \\
\hline $\mathrm{Ce}-30$ & $1.35(8)$ & Rev-Ce-30 & $0.16(11)$ \\
\hline $\mathrm{Ce}-60$ & $2.71(2)$ & Rev-Ce-60 & $0.15(5)$ \\
\hline $\mathrm{Ce}-90$ & $3.95(6)$ & Rev-Ce-90 & $0.35(32)$ \\
\hline $\mathrm{Ce}-180$ & $6.20(15)$ & Rev-Ce-180 & $0.29(12)$ \\
\hline $\mathrm{Ce}-290$ & $6.55(60)$ & Rev-Ce-290 & $0.23(10)$ \\
\hline Ce-750 & $6.83(32)$ & Rev-Ce-750 & $0.20(10)$ \\
\hline
\end{tabular}

An almost complete release of cerium is obtained for all the samples. The effectiveness of the final exchange is also shown by the nitrogen content (Table S5), which recovers the original value of $\mathrm{NH}_{4}-\mathrm{LTL}$. To test the impact of these treatments on the zeolite structure and evaluate the possible reuse of the same zeolite powder in further cycles of Ce recovery, $\mathrm{X}$ ray powder diffraction patterns before and after the whole process were collected for the two most promising samples. In Figure 6 , the diffraction pattern of the original $\mathrm{NH}_{4}-\mathrm{L}$ (Confalonieri et al. 2021) is compared with that of samples $\mathrm{Ce}-90$ and $\mathrm{Ce}-180$ before and after the cerium recovery. The two samples containing cerium clearly show differences in the peak intensity ratios related to the incorporation of the REE in comparison to the original $\mathrm{NH}_{4} \mathrm{~L} L$ (Figure 6 left panel), structural modifications are described elsewhere (Confalonieri et al. 2021). These changes 
disappear completely after the second exchange with $\mathrm{NH}_{4}{ }^{+}$solution (Figure 6 right panel), demonstrating a complete recovery of cerium. Neither structure modifications nor loss of crystallinity was detected.

\subsection{Comparison with other adsorbent materials}

The adsorption capacity of the two most promising samples was calculated as in Zhao et al. (2019):

$$
q_{t}=\left(C_{0}-C_{t}\right) V / m
$$

where $C_{0}$ and $C_{t}$ are the initial concentration and the residual concentration $(\mathrm{mg} / \mathrm{L})$ of Ce in the solution, $V$ is the volume of $\mathrm{Ce}^{3+}$ solution $(\mathrm{L}), m$ is the weight of the zeolite (g).

Ce-90 and Ce-180 show a cerium adsorption capacity $\left(\mathrm{q}_{\mathrm{t}}\right)$ equal to $\sim 25 \mathrm{mg} / \mathrm{g}$ and $\sim 39 \mathrm{mg} / \mathrm{g}$, respectively, for an initial $\mathrm{Ce}^{3+}$ concentration of $280 \mathrm{mg} / \mathrm{L}$. Interesting evaluations can be made comparing the value calculated for $\mathrm{Ce}-180$ with those obtained for other materials in similar conditions, such as those described in the review by De Farias et al. (2021). Our sample displays higher adsorption capacity than some reported adsorbents such as poly-y-glutamic acid crosslinked with polyvinyl alcohol (Gao et al. 2015), which was, by the way, studied at lower concentration $(100 \mathrm{mg} / \mathrm{L})$, cyanobacteria of the genus Arthrospira (Sadovsky et al. 2016), as well as for some treated olive pomace (Akbas \&Yusan 2020). Similar performances, instead, are obtained by a novel hybrid inorganic materials $\mathrm{H}_{n} \mathrm{PMo}_{12} \mathrm{O}_{40} @ \mathrm{Fe}(\mathrm{III})_{x} \mathrm{Sn}(\mathrm{II})_{y} \mathrm{Sn}(\mathrm{IV})_{1-x-y}$ (Yousefi et al. 2015) only if compared in similar experimental conditions (temperature, $25^{\circ} \mathrm{C}, \mathrm{pH}, \sim 4$, while the concentration is lower, $100 \mathrm{mg} / \mathrm{L}$ ). Differently, higher cerium adsorption capacity is shown by HKUST-1 metal-organic framework (MOF) (353 mg/g), but the subsequence process for REE recovery (methanol washing) is not able to completely remove the absorbed $\mathrm{Ce}^{3+}$. A high value is also displayed by monolithic multi-porous carboxymethyl cellulose-g-poly (acrylamide)/attapulgite $(205,48 \mathrm{mg} / \mathrm{g})$, where the final cerium recuperation was obtained using $\mathrm{HCl}$ solution, while the material was regenerated through $\mathrm{NaOH}$ solution with the need of neutralisation and formation of salt wastes (Wang et al. 2020).

Even if other materials showed adsorption capacity similar or higher than those shown by our systems (i.e. marine algae (Vijayaraghavan et al. 2010), polymers (Maruthapandi et al. 2020), etc. (de Farias et al. 2021), the use of zeolites has many advantages and indicates them as potential interesting adsorbents to be exploited for a green recovery of REE. In fact, first of all, cationic zeolite syntheses are easy and do not require exotic and expensive organic chemicals to be realized, moreover, it could be considered that this work can pave the way to the use of natural zeolites (zeolitites) for REE recovery, and this will further improve the sustainability of the process. No energy cost for temperature setting is required and $\mathrm{NH} 4+$ solution can be recycled over different cycles. Zeolites proved to have high framework stability at low pH, compatible with the acidity of industrial leached liquor and this, along with their effectiveness in releasing all the exchanged cations, allows their use for several cycles.

\section{Conclusions}


$\mathrm{NH}_{4}{ }^{+}$-exchanged zeolite $\mathrm{L}$ demonstrated to be a suitable candidate for cerium recovery from a diluted solution $\left(\left[\mathrm{Ce}^{3+}\right]=0.002 \mathrm{M}\right.$ ), which mimics the leached liquor from the residual waste of some industrial processes. Our work indicates that $100 \%$ of cerium can be already extracted in batch from the solution at room temperature, with a liquid/solid ratio of $90 \mathrm{~mL} / \mathrm{g}$ and $24 \mathrm{~h}$ of contact between zeolite and solution. With a liquid/solid ratio of $180 \mathrm{~mL} / \mathrm{g}, 77 \% \mathrm{Ce}^{3+}$ in solution is exchanged in $24 \mathrm{~h} \mathrm{by} \mathrm{NH}_{4}{ }^{+}$of the zeolite and the zeolite approaches its maximum capacity, being ready for an effective counter-exchange cycle. In complete cycles of uptake and release of cerium, the counter-exchange of $\mathrm{NH}_{4}{ }^{+}$for $\mathrm{Ce}^{3+}$ allowed the complete cerium recovery. The kinetics of the process was proved to be fast and consistent with industrial timing, no energy cost for temperature setting is required and acid conditions of the solutions do not affect the zeolite structure. Despite the $\mathrm{NH}_{4}-\mathrm{L}$ should be tested in a more complex system (i.e. with a multicomponent solution), which better simulates a leached liquor, the obtained results are very promising for future industrial applications. This work can pave the way for the use of zeolites as "green tools" to recover REE from liquor of different nature in a circular economy perspective.

\section{Declarations}

\section{Acknowledgments}

The authors thank Gianluca Malavasi and Lorenzo Tassi for the laboratory equipment, and Massimo Tonelli, Monica Malavasi, Monica Vaccari, Simona Bigi and Michelangelo Polisi for their technical support.

\section{Ethical Approval}

Not applicable

\section{Consent to Participate}

Not applicable

\section{Consent to Pubblish}

All authors agreed with the content and that all gave explicit consent to submit. They obtained consent from the responsible authorities at the institute/organization where the work has been carried out.

\section{Funding}

The authors declare that no funds, grants, or other support were received during the preparation of this manuscript.

\section{Competing Interests}

The authors have no relevant financial or non-financial interests to disclose. 


\section{Author Contributions}

All authors contributed to the study conception and design. Material preparation, data collection and analysis were performed by Giorgia Confalonieri, Vittorio Gozzoli e Laura Maletti. The first draft of the manuscript was written by Giorgia Confalonieri and all authors commented on previous versions of the manuscript. All authors read and approved the final manuscript.

\section{Data and materials}

All the data are available in the supporting information file. Further data can be requested to the authors

\section{References}

1. Akbas YA, Yusan S (2020) Development and characterization of non-treated and chemically modified olive pomace biosorbents to remove Ce(III) ions from aqueous solutions. J. Radioanal. Nucl. Chem. 323: 763-772

2. Bacakova L, Vandrovcova M, Kopova I, Jirka I (2018) Applications of zeolites in biotechnology and medicine - a review. Biomat. Sci. 6: 974-989

3. Baerlocher C, McCusker LB Database of Zeolite Structures, http://www.iza-structure.org/databases/

4. Barros O, Costa L, Costa F, Lago A, Rocha V, Vipotnik Z, Silva B, Tavares T (2019) Recovery of Rare Earth Elements from Wastewater Towards a Circular Economy. Molecules 24: 1005

5. Binnemans K, Jones PT, Blanpain B, Van Gerven T, Yang YX, Walton A, Buchert M (2013) Recycling of rare earths: a critical review. J. Clean. Prod. 51: 1-22

6. Binnemans K, Jones PT, Müller T, Yurramendi L (2018) Rare Earths and the Balance Problem: How to Deal with Changing Markets? J. Sustain. Metall. 4: 126-146

7. Borra CR, Vlugt TJH, Yang YX, Offerman SE (2018) Recovery of Cerium from Glass Polishing Waste: A Critical Review. Metals 8: 801

8. Breck DW (1984): Zeolite Molecular Sieves, 2nd Edition. Krieger, Malabar (FL) 529-592 pp

9. Calzaferri G, Huber S, Maas H, Minkowski C (2003) Host-guest antenna materials. Angew. Chem. Int. Ed. 42: $3732-3758$

10. Čejka J, Corma A, Zones S (2010): Zeolite and Catalysis. Synthesis, Reactions and Applications. Wyley-YCH, Weinheim

11. Chang TM, Dang LX (2003) On rotational dynamics of an NH4+ ion in water. Chem. Phys. 118: 88138820

12. Charalampides G, Vatalis KI, Apostoplos B, Ploutarch-Nikolas B (2015) Rare Earth Elements: Industrial Applications and Economic Dependency of Europe. Procedia Econ. Financ. 24: 126-135

13. Confalonieri G, Ryzhikov A, Arletti R, Nouali H, Quartieri S, Daou TJ, Patarin J (2018) IntrusionExtrusion of Electrolyte Aqueous Solutions in Pure Silica Chabazite by in Situ High Pressure Synchrotron X-ray Powder Diffraction. J. Phys. Chem. C 122: 28001-28012 
14. Confalonieri G, Daou TJ, Nouali H, Arletti R, Ryzhikov A (2020) Energetic Performance of Pure Silica Zeolites under High-Pressure Intrusion of LiCl Aqueous Solutions: An Overview. Molecules 25: 2145

15. Confalonieri G., Vezzalini G., Quattrini F., Quartieri S., Dejoie C., Arletti R. (2021) Ce-exchange capacity of zeolite $L$ in different cationic forms: a structural investigation. J. Appl. Crystallogr. 54: 1766-1774

16. Corma A (2003) State of the art and future challenges of zeolites as catalysts. J. Catal. 216: 298-312

17. Coudert FX, Kohen D (2017) Molecular Insight into CO2 "Trapdoor" Adsorption in Zeolite Na-RHO. Chem. Mater. 29: 2724-2730

18. de Aquino TF, Estevam ST, Viola VO, Marques CRM, Zancan FL, Vasconcelos LB, Riella HG, Pires MJR, Morales-Ospino R, Torres AEB, Bastos-Neto M, Cavalcante CL (2020) CO2 adsorption capacity of zeolites synthesized from coal fly ashes. Fuel 276: 118143

19. de Farias ABV, da Costa TB, da Silva MGC, Vieira MGA (2021) Cerium recovery from aqueous solutions by bio/adsorption: A review in a circular economy context. J. Clean. Prod. 326: 129395

20. Duplouy L 2016: Preliminary Investigation of Rare Earth Elements Ion Exchange on Zeolites, University of Helsinki, Université de Lille

21. Eroglu N, Emekci M, Athanassiou CG (2017) Applications of natural zeolites on agriculture and food production. J. Sci. Food Agric. 97: 3487-3499

22. Eroshenko V, Regis RC, Soulard M, Patarin J (2001) Energetics: A new field of applications for hydrophobic zeolites. J. Am. Chem. Soc. 123: 8129-8130

23. Fabbiani M, Confalonieri G, Morandi S, Arletti R, Quartieri S, Santoro M, Di Renzo F, Haines J, Fantini R, Tabacchi G, Fois E, Vezzalini G, Ricchiardi G, Martra G (2021) Steering polymer growth by molding nanochannels: 1,5-hexadiene polymerization in high silica mordenite. Microporous and Mesoporous Mater. 311: 110728

24. Faghihian H, Amini MK, Nezamzadeh AR (2005) Cerium uptake by zeolite A synthesized from natural clinoptilolite tuffs. J. Radioanal. Nucl. Chem. 264: 577-582

25. Gao YQ, Zhang SM, Zhao KY, Wang ZW, Xu SX, Liang ZP, Wu K (2015) Adsorption of La3+ and Ce3+ by poly-gamma-glutamic acid crosslinked with polyvinyl alcohol. J. Rare Earths 33: 884-891

26. Gigli L, Arletti R, Tabacchi G, Fabbiani M, Vitillo JG, Martra G, Devaux A, Miletto I, Quartieri S, Calzaferri G, Fois E (2018) Structure and Host-Guest Interactions of Perylene-Diimide Dyes in Zeolite L Nanochannels. J. Phys. Chem. C 122: 3401-3418

27. Gorte RJ (2010) Ceria in Catalysis: From Automotive Applications to the Water Gas Shift Reaction. AIChE 56: 1126-1135

28. Gottardi G, Galli E (1985): Natural Zeolites. Minerals, Rocks and Mountains. Springer-Verlag Berlin Heidelberg

29. Haque N, Hughes A, Lim S, Vernon C (2014) Rare Earth Elements: Overview of Mining, Mineralogy, Uses, Sustainability and Environmental Impact. Resources 3: 614-635

30. Hong SH, Jang MS, Cho SJ, Ahn WS (2014) Chabazite and zeolite 13X for CO2 capture under high pressure and moderate temperature conditions. Chem. Commun. 50: 4927-4930 
31. Ilyas S, Kim H, Srivastava RR (2021) Hydrometallurgical Recycling of Rare Earth Metal-Cerium from Bio-processed Residual Waste of Exhausted Automobile Catalysts. JOM 73: 19-26

32. Innocenzi V, Ferella F, De Michelis I, Veglio F (2015) Treatment of fluid catalytic cracking spent catalysts to recover lanthanum and cerium: Comparison between selective precipitation and solvent extraction. J. Ind. Eng. Chem. 24: 92-97

33. Krajnc A, Varlec J, Mazaj M, Ristic A, Logar NZ, Mali G (2017) Superior Performance of Microporous Aluminophosphate with LTA Topology in Solar-Energy Storage and Heat Reallocation. Adv. Energy Mater. 7

34. LeVan MD, Carta G, Yon CMRHP, D.W. Green (Eds.) (1997): Adsorption and Ion Exchange. In: Perry RH , Green DW (Editors), Perry's Chemical Engineering Handbook, 7th Edition. McGraw-Hill, New York

35. Lutz OMD, Hofer TS, Randolf BR, Rode BM (2012) Computational study of the cerium(III) ion in aqueous environment. Chem. Phys. Lett. 539: 50-53

36. Mancheri NA, Sprecher B, Bailey G, Ge JP, Tukker A (2019) Effect of Chinese policies on rare earth supply chain resilience. Resour. Conserv. Recycl. 142: 101-112

37. Maruthapandi M, Luong JHT, Gedanken A (2020) Nitrogen-Enriched Porous Benzimidazole-Linked Polymeric Network for the Adsorption of La (III), Ce (III), and Nd (III). J. Phys. Chem. C 124: 6206-6214

38. Mendez-Arguello B, Lira-Saldivar RH (2019) Potential use of zeolite on sustainable agriculture for the new green revolution. Ecosistemas Y Recursos Agropecuarios 6: 191-193

39. Meshram P, Abhilash (2020) Recovery and Recycling of Cerium from Primary and Secondary Resources- a Critical Review. Miner. Process. Extr. Metall. Rev. 41: 279-310

40. Mosai AK, Chimuka L, Cukrowska EM, Kotze IA, Tutu H (2019) The Recovery of Rare Earth Elements (REEs) from Aqueous Solutions Using Natural Zeolite and Bentonite. Water Air and Soil Pollut. 230: 188

41. Nakhli SAA, Delkash M, Bakhshayesh BE, Kazemian H (2017) Application of Zeolites for Sustainable Agriculture: a Review on Water and Nutrient Retention. Water Air and Soil Pollut. 228: 464

42. Porvali A, Agarwal V, Lundstrom M (2020) REE(III) recovery from spent NiMH batteries as REE double sulfates and their simultaneous hydrolysis and wet-oxidation. Waste Manage. (Oxford) 107: 66-73

43. Ramesh K, Reddy DD, Biswas AK, Rao AS (2011) Zeolites and Their Potential Uses in Agriculture. Advances in Agronomy, Vol 113 113: 215-236

44. Royen H, Fortkamp U (2016) Rare Earth Elements - Purification, Separation and Recycling. Report of IVL Swedish Environmental Research Institute 2016

45. Sadovsky D, Brenner A, Astrachan B, Asaf B, Gonen R (2016) Biosorption potential of cerium ions using Spirulina biomass. J. Rare Earths 34: 644-652

46. Soulard M, Patarin J (2011): Process for High-Pressure Energy Storage by Solvation/Desolvation and Associated Storage Device. Patent, France

47. Stylianou MA (2012) Natural Zeolites in Medicine. Handbook of Natural Zeolites: 317-334 
48. Suli LM, Ibrahim WHW, Aziz BA, Deraman MR, Ismail NA (2017) A Review of Rare Earth Mineral Processing Technology. Chem. Eng. Res. Bull. 19: 20

49. Tunsu C, Ekberg C, Foreman M, Retegan T (2016) Targeting fluorescent lamp waste for the recovery of cerium, lanthanum, europium, gadolinium, terbium and yttrium. Transactions of the Institutions of Mining and Metallurgy Section C-Mineral Processing and Extractive Metallurgy 125: 199-203

50. Vijayaraghavan K, Sathishkumar M, Balasubramanian R (2010) Biosorption of Lanthanum, Cerium, Europium, and Ytterbium by a Brown Marine Alga, Turbinaria Conoides. Ind. Eng. Chem. Res. 49: 4405-4411

51. Wang F, Zhu YF, Wang AQ (2020) Preparation of Carboxymethyl Cellulose-gPoly(acrylamide)/Attapulgite Porous Monolith With an Eco-Friendly Pickering-MIPE Template for $\mathrm{Ce}(\mathrm{III})$ and Gd(III) Adsorption. Frontiers in Chemistry 8: 398

52. Yousefi T, Yavarpour S, Mousavi SH, Torab-Mostaedi M, Davarkhah R, Mobtaker HG (2015) Effective removal of $\mathrm{Ce}$ (III) and $\mathrm{Pb}$ (II) by new hybrid nano-material: HnPMo12040@Fe(III)(x)Sn(II)(y)Sn(IV)(1-xy). Process Saf. Environ. Prot. 98: 211-220

53. Yurramendi L, Gijsemans L, Forte F, Aldana JL, del Rio C, Binnemans K (2019) Enhancing rare-earth recovery from lamp phosphor waste. Hydrometallurgy 187: 38-44

54. Zhao L, Azhar MR, Li XJ, Duan XG, Sun HQ, Wang SB, Fang XC (2019) Adsorption of cerium (III) by HKUST-1 metal-organic framework from aqueous solution. J. Colloid Interface Sci. 542: 421-428

55. Zhao ZX, Qiu ZF, Yang J, Ma BT, Li Z, Lu SG, Xu YY, Cao LM, Zhang W (2020) Recovery of Rare Earth Element Cerium from Spent Automotive Exhaust Catalysts Using a Novel Method. Waste and Biomass Valorization 11: 4967-4976

\section{Figures}

\section{Figure 1}

Nutshell of the process. 


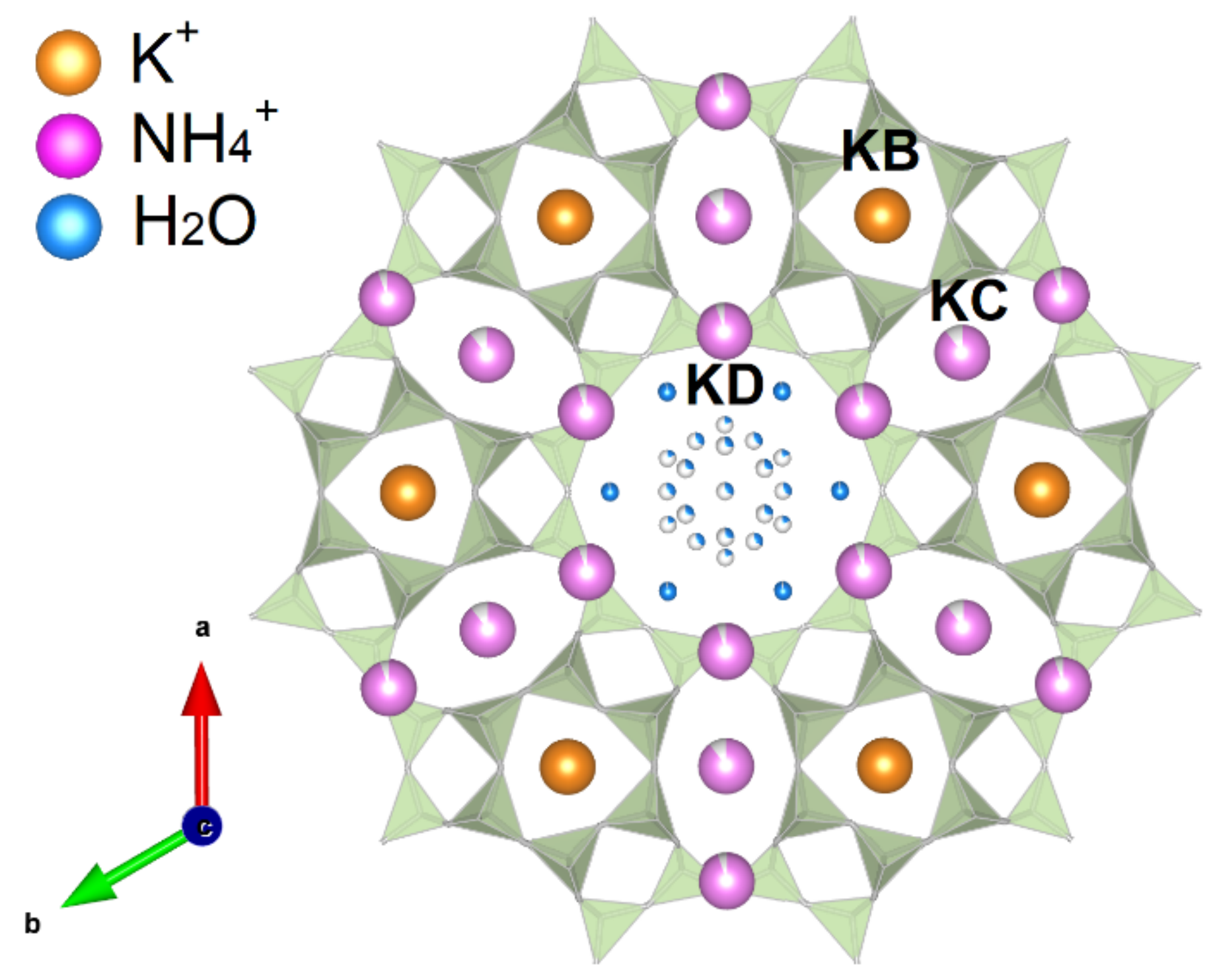

Figure 2

Structure of $\mathrm{NH}_{4}{ }^{+}$-exchanged zeolite $\mathrm{L}$ with chemical formula $\mathrm{K}_{2.25}\left(\mathrm{NH}_{4}\right)_{6.86} \mathrm{Si}_{26.91} \mathrm{Al}_{9.08} \mathrm{O}_{72} \cdot 17.07\left(\mathrm{H}_{2} \mathrm{O}\right)$. The extraframework species are drawn showing the fractional occupancy of their crystallographic sites (Confalonieri et al. 2021). 


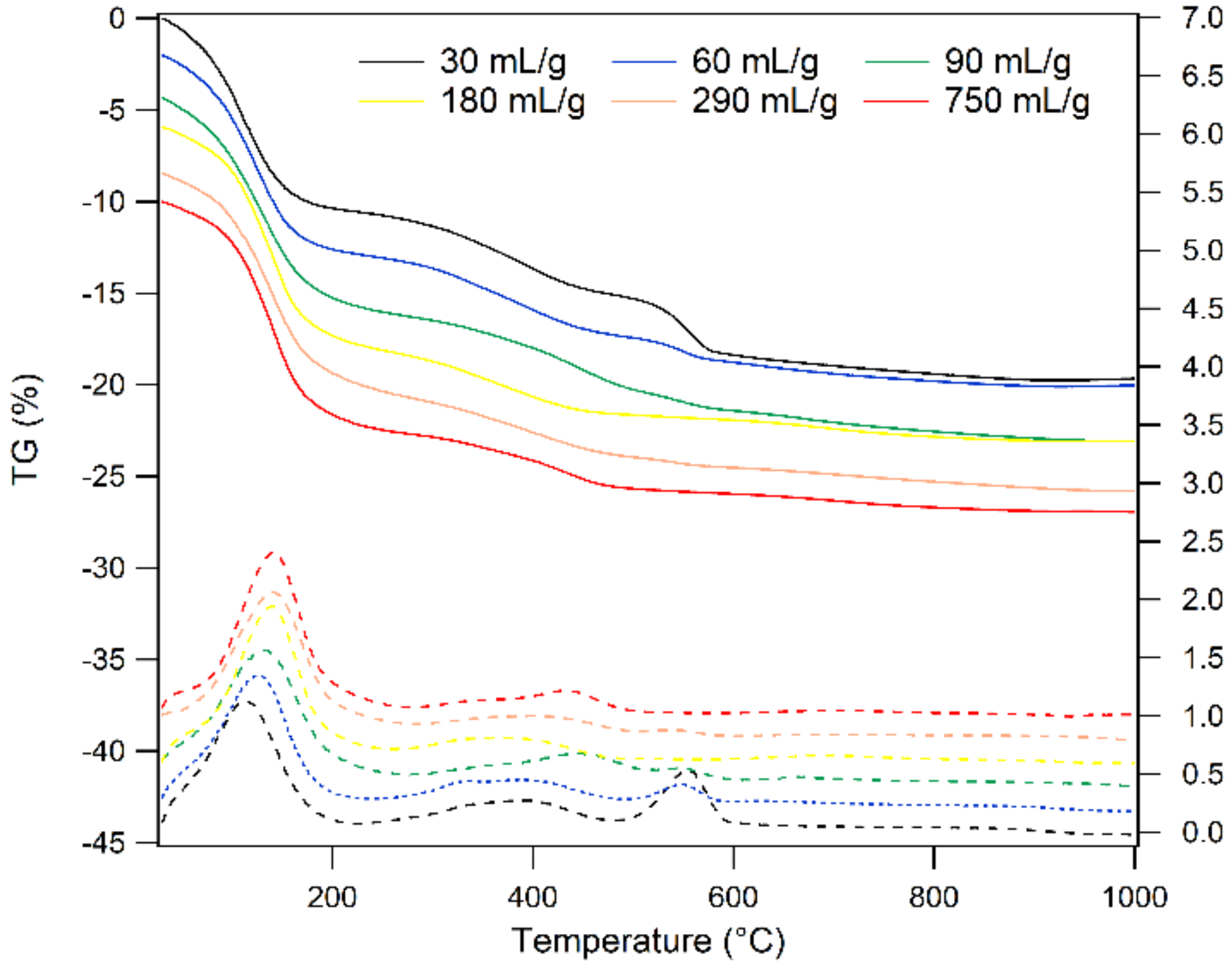

$\frac{0}{0} \frac{0}{0}$

Figure 3

TG (solid line) and DTG (dotted line) curves for zeolite samples exchanged with cerium. For a more readable figure, every TG curve is progressively shifted along y axis of about $-2 \%$, while the corresponding DTG one is shifted progressively along y axis of about $0.2 \% /{ }^{\circ} \mathrm{C}$. 
$\mathbb{\Delta}$ Total Exchange

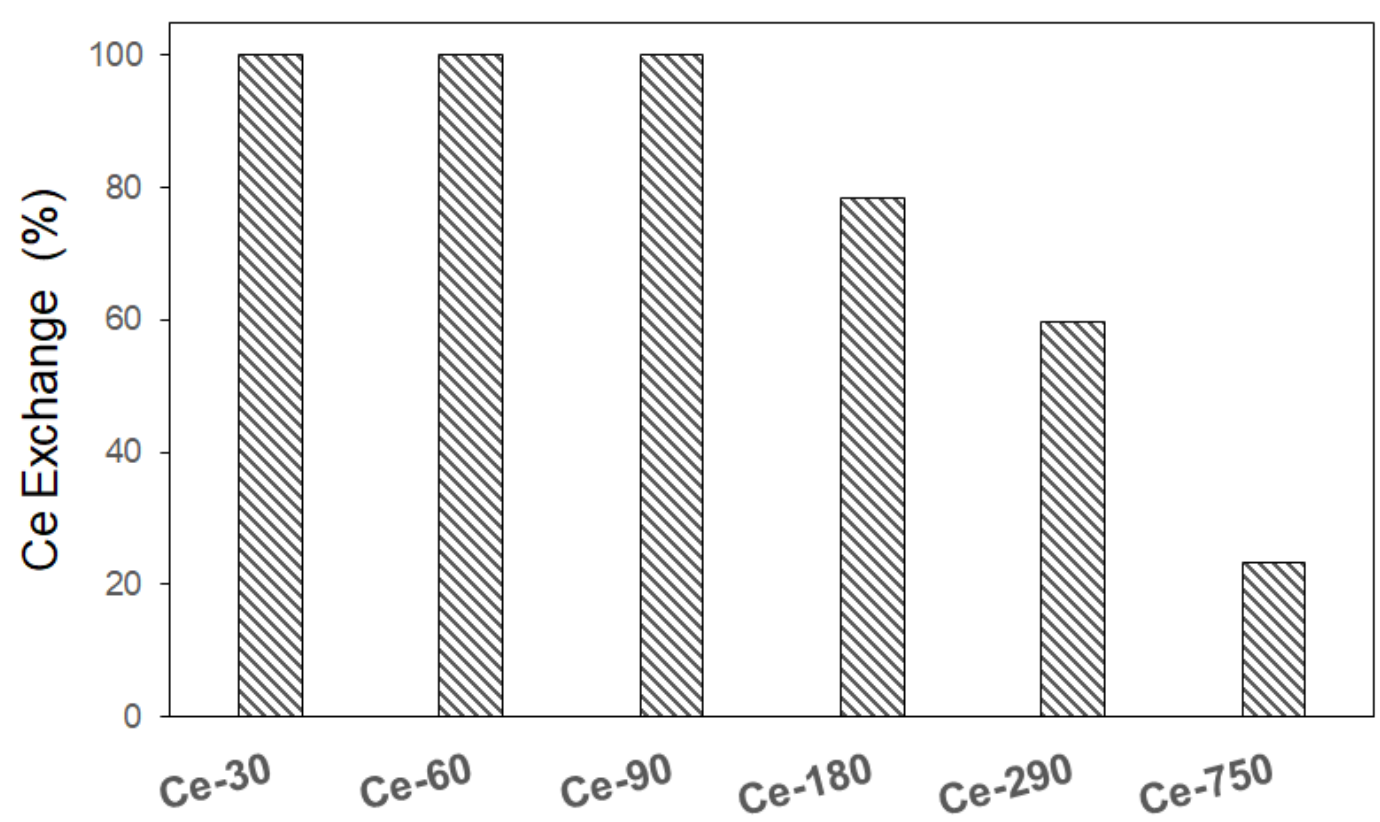

- $24 \mathrm{~h} \square 48 \mathrm{~h} \square 72 \mathrm{~h}$

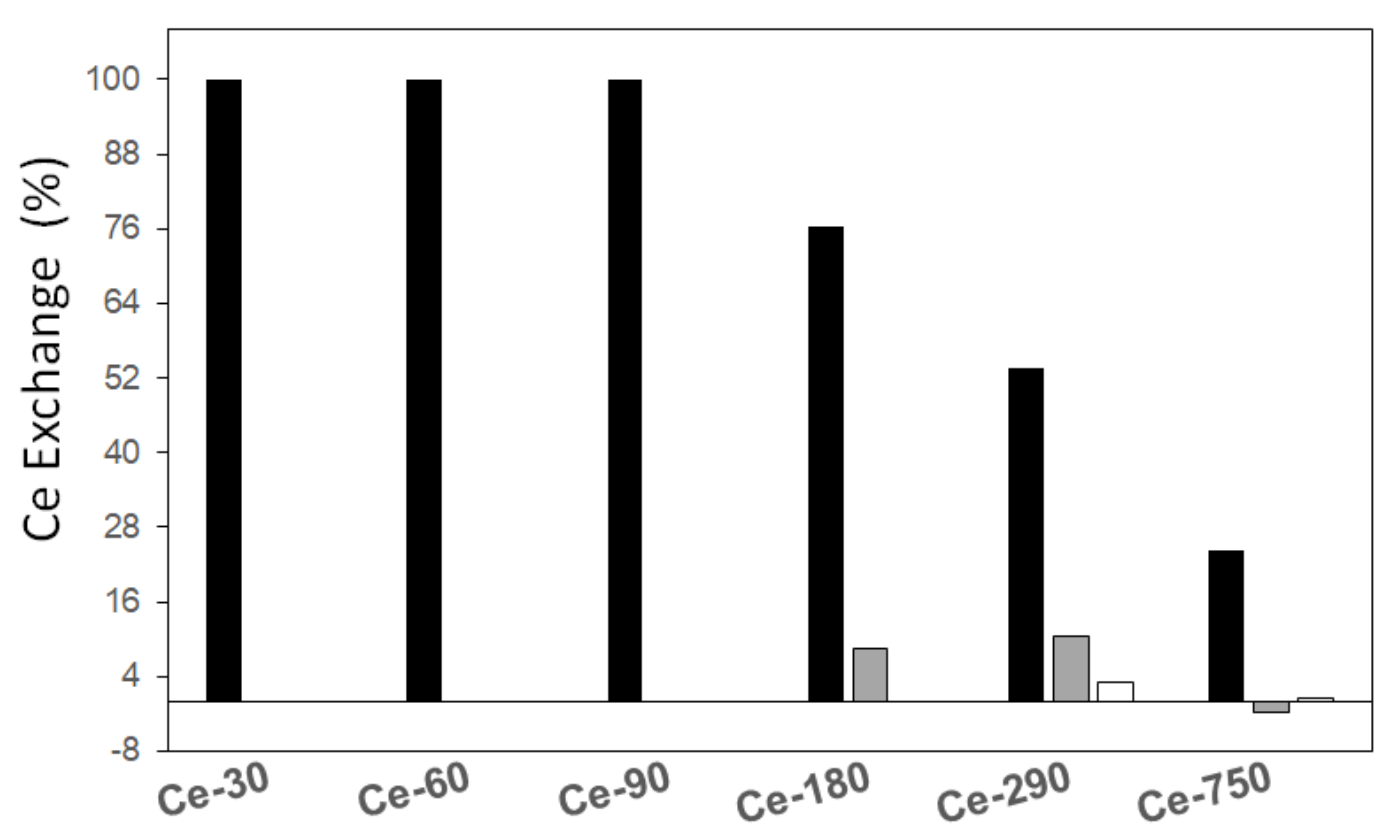

Figure 4

Percentage of Ce withdrawn from the solution (i.e. exchanged) by the zeolite after three days of contact with the solutions at various liquid/solid ratios. The total percentage of exchanged Ce is reported in the top panel, while in the bottom one the Ce percentage after $24,48,72 \mathrm{~h}$ is shown. The anomalous behaviour of sample Ce-750 is explained in Table S3. 


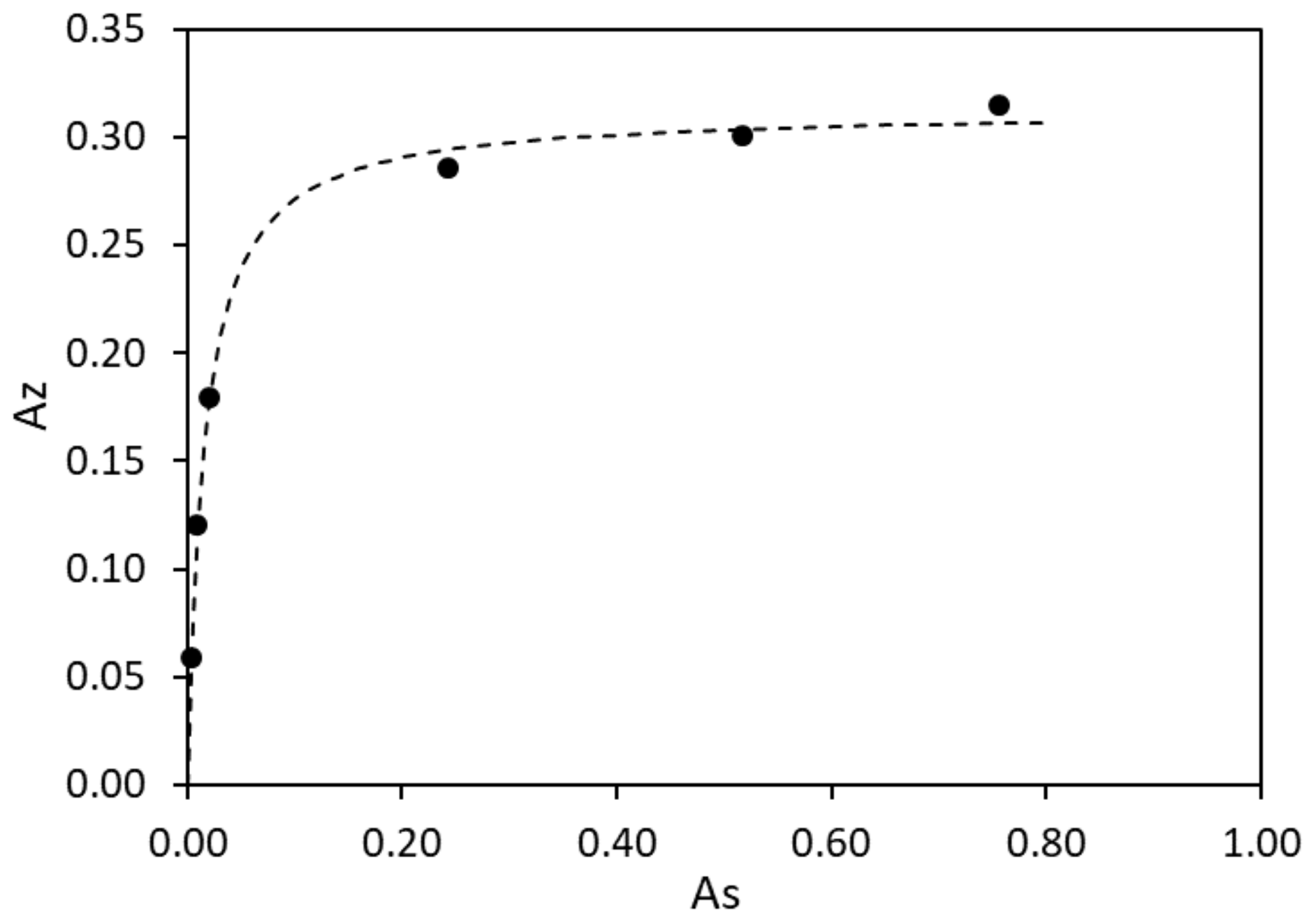

Figure 5

Cerium-ammonium exchange isotherm in $\mathrm{NH}_{4}-L T L$. The experimental points are expressed as $\mathrm{Az} v s \mathrm{As}$, where $\mathrm{Az}=3 \mathrm{Ce}^{3+} / \mathrm{Al}$ (molar) in the zeolite and $\mathrm{As}=\mathrm{C}\left(\mathrm{Ce}^{3+}\right) /$ initial $\mathrm{C}\left(\mathrm{NH}^{4+}\right)$ (equivalents) in solution.

\section{Figure 6}

Comparison between XRPD patterns of NH4-L (Confalonieri et al. 2021) and of the samples Ce-90 and Ce-80 before (left panel) and after (right panel) cerium recovery.

\section{Supplementary Files}

This is a list of supplementary files associated with this preprint. Click to download.

- supplementaryinf.docx 